by experience that other things may buzz besides its natural food.

If the spider is not at the centre of the web at the time that the fork is applied, it cannot tell which way to go until it has been to the centre to ascertain which radial thread is vibrating, unless of course it should happen to be on that particular thread or on a stretched supporting thread in contact with the fork.

If when a spider has been enticed to the edge of the web the fork is withdrawn and then gradually brought near, the spider is aware of its presence and of its direction, and reaches out as far as possible in the direction of the fork ; but if a sounding fork is gradually brought near a spider that has not been disturbed, but which is waiting as usual in the middle of the web, then instead of reaching out towards the fork the spider instantly drops-at the end of a thread of course. If under these conditions the fork is made to touch any part of the web, the spider is aware of the fact and climbs the thread and reaches the fork with marvellous rapidity. The spider never leaves the centre of the web without a thread along which to travel back. If after enticing a spider out we cut this thread with a pair of scissors, the spider seems to be unable to get back without doing considerable damage to the web, generally gumming together the sticky parallel threads in groups of three and four.

By means of a tuning-fork a spider may be made to eat what it would otherwise avoid. I took a fly that had been drowned in paraffin and put it into a spider's web and then attracted the spider by touching the fly with a fork. When the spider had come to the conclusion that it was not suitable food and was leaving it, I touched the fly again. This had the same effect as before, and as often as the spider began to leave the fly I again touched it, and by this means compelled the spider to eat a large portion of the fly.

The few house-spiders that I have found do not seem to appreciate the tuning-fork, but retreat into their hidingplaces as when frightened; yet the supposed fondness of spiders for music must surely have some connection with these observations, and when they come out to listen is it not that they cannot tell which way to proceed?

The few observations that I have made are necessarily imperfect, but I send them, as they afford a method which might lead a naturalist to notice habits otherwise difficult to observe, and so to arrive at conclusions which I in my ignorance of natural history must leave to others.

Physical Laboratory, South Kensington

\section{THE MINERALOGICAL SOCIETY OF GREAT BRITAIN AND IRELAND}

THERE was a time, now almost beyond the memory even of the oldest inhabitant, when the stillness of our learned halls was unbroken by the wrangle of contending geologists, when the science of geology could not be said yet to exist, when those who occupied themselves with stones found a congenial atmosphere of solemnity in the quiet domain of crystallography, whence with the boldness of adventurers they made little excursions into the more open and dangerous waters of chemistry. Days of slumberous peace as they now seem to one who turns over the ponderous dusty pages in which their records are duly chronicled! To the mineralogist of those days the interest and importance of rock-masses was measured by their richness or poorness in mineral specimens. Surrounded by his cases of minerals-the reward of years of patient toil and judicious expenditure, with what tender interest would he survey his treasures! We knew him in old times, yea and loved him. Enthusiastically would be describe how he had contrived to secure that priceless unique crystal; how day after day he had searched the rocks in vain, till at last one lucky stroke of the hammer laid open that magnificent druse; how he had bought that matchless group from a sailor who used it to keep down the lid of his tobacco box. Kindly too he was, and all the more if you took interest in his favourite pursuit. Ask him to tell you the difference between two resembling minerals, and he would launch out with evident relish into his "external characters." Lovingly would he handle the specimens, as if they were the children of his old age. Eagerly would he descant upon the difference between "lamellar distinct concretions"; how some were "indeterminate curved lamellar," others were "fortifications-wise bent." And then would follow the whole string of characters-" semi-hard," "not particularly diffcultly frangible," "supernatant," "pretty cold," "not par ticularly heavy," between "aurora-red" and "hyacinthred," or between "mountain-green" and "celandinegreen." Such jargon it seemed to youthful ears! One could not but admire indeed its methodical precision, but the questions ever forced themselves on one's mind-What is the living truth underlying it all? Were minerals really created merely as a basis for our old friend's systems of classification? Or can they not be made to yield up some intelligible record of their own history and of the planet of which they form a part?

When the discoveries of William Smith drew off the attention of students to the marvels revealed by stratigraphical geology, mineralogy rapidly sank into neglect in this country. By a curious revulsion of opinion rocks were now appraised as of importance in proportion as mere mineral specimens were absent from them, for where these occurred organic remains were usually not to be looked for; and organic remains now took the place of minerals. Men who would formerly have trudged cheerfully a whole day with a I4-lb. hammer on their shoulders to secure a few minerals were now to be seen as enthusiastically hunting for ammonites, gryphaeas, belemnites, echini, fossil fishes, and other buried treasures of the stratified formations. Unmeasured was the scorn of the veteran mineralogist for this new-fangled pursuit. To neglect such attractive objects as minerals, with their exquisite forms and colours, for the dingy and fragmentary relics of extinct whelks, lobsters, and other pre-adamite vermin seemed to him an utterly unaccountable form of madness. And so his beloved cabinet became dearer to him than ever. In its quiet retreat he lived with his specimens in the past, and allowed the strong rising tide of palæontology to rush and roar past him unheeded.

But cycles appear in scientific as in political opinion. For some years past there has been a growing conviction that palæontology has had a long enough monopoly of power in the geological commonwealth, and that the mineral ogical side of the science has in this country been unduly neglected and discouraged. The attention now bestowed among us upon petrographical research is a pleasing proof of the reality and steady progress of this reaction. Another token of the same change is supplied by the foundation and encouraging growth of the Mineralogical Society of Great Britain and Ireland. This society was instituted in the early part of the year 1876 . It counts among its members a large and increasing number of the best geologists in the three kingdoms. But its operations are carried on so quietly and unostentatiously that its work and aims are probably not yet so widely known as they deserve to be. A body gathered under the leadership of Sorby and Heddle is one which may count on support from all to whom the advancement of mineralogy and mineralogical geology among us is an object of interest. As a rule our scientific societies are bodies with a local habitation, gathering most of their effective members from the district in which their rooms are placed. But the Mineralogical Society, as its name denotes, embraces the whole United Kingdom. It has no buildings of its own nor any one special home. Its meetings, like those of the British Association on a large scale, are 
held from time to time in different towns throughout the country, its object being to form a bond of union among those who cultivate mineralogy or who wish to see this science restored to the place which it ought to hold in a land where so much scund geological work is being done. The Society publishes a "Mineralogical Magazine," of which three volumes and part of a fourth have already appeared. This publication contains numerous papers by Dr. Heddle and the indefatigable secretary, Mr. Collins, also some by Mr. Sorby, the late Mr. J. C. Ward, Prof. Bonney, and other well-known writers. No one need fear to encounter in its pages the resuscitated ghosts of the old mineralogical "Dryasdusts." Peace to their manes! They did good though limited work in their day, which deserves our respect for its thoroughness. But, with affectionate reverence for these early masters and their crabbed lingo, we breathe a more open breezy atmosphere now. The mineralogist's ken sweeps far beyond the limits of his cabinet and laboratory. Hand-in-hand with the geologist and palæontologist, being elder brother to both, he takes his share in the task of unravelling the structure and history of the earth. Towards the attainment of this union the Mineralogical Society aims, and it deserves the heartiest wishes for its success.

ARCH. GEIKIE

\section{SMOKELESS LONDON}

T WRITE for the purpose of expounding a scheme which, if adopted, would make London a smokeless city.

When taking upon myself to explain a subject in a few minutes which has taken many years to develop ir my own mind, there is a great temptation to put the reader in possession of the steps which led to the conclusion. The conclusion itself however has so much to recommend it that I will confine myself to the results of my reasoning only. It is enough to say that they were arrived at to a great extent by an exhaustive exclusion of less feasible plans.

First then I propose to take advantage of the existing plant of the gas companies. I find they are amply sufficient for the purpose.

Instead of taking I0,000 cubic feet of gas per ton from the coal, I propose to take 3333 cubic feet, and to pass three times the quantity through the retorts, or any other proportion that may be found most convenient. The result of doing so is startling.

The companies will have double the quantity of byproducts they have at present in the shape of tar and ammoniacal liquids; the community will have 24 -candle gas instead of 16 -candle gas; the fuel resulting from the process will light readily, and it will make a cheerful fire that gives out 20 per cent. more heat than common coal; London would become a smokeless city.

In dealing with the figures I shall take them roughly, but in such a way that by including a few outlying corporations they could be made absolutely correct.

I take the total annual consumption of coal in London to be $6,000,000$ tons. Of this I take $2,000,000$ tons to be the annual consumption of the gas companies. The total quantity of fuel used for general purposes I take to be $4,000,000$ tons of coal and $1,000,000$ tons of coke sold by the gas companies.

We shall now see what would be the result if we treat the whole of the 6,000,000 tons in the retorts on an extraction of less than three hours, instead of the six hours at present prevailing.

The total quantity of 16-candle gas consumed in London may be taken at $20,000,000,000$ cubic feet. This would be at the rate of 3333 cubic feet per ton upon 6,000,000 tons, the total quantity of coal consumed in London. The residual smokeless fuel would amount to 5, 100,000 tons. Of this $1,000,000$ tons would be required for the extraction of the gas, leaving 4,100,000 available for the general uses of the community. This has to be compared with the 4,000,000 tons of coal and the $1,000,000$ tons of coke already referred to as consumed at present. Now the smokeless fuel which results from an extraction of 3333 cubic feet of gas per ton has a heating capacity fully 20 per cent. greater than common coal, and ro per cent. greater than coke. This gives us the exact equivalents of the 5,000,000 tons of fuel at present in use.

So far the account as regards the fuel available for the community balances. We may now deal with the differ ence in value between I6 and 24-candle gas. As the value of the gas varies directly as its illuminating power, the calculation is very simple. If we take the average price of 16 -candle-gas to be $3 s .6 \mathrm{~d}$. per thousand cubic feet we shall find the total value of the $20,000,000,000$ consumed in London to be $3,500,000$ l, but as we have by my scheme the same quantity of 24 -candle-gas, the value will be increased to $5,250,000 l$. ; here then we have an annual sum of $1,750,000 l$. to place to the credit of the system.

Turning now to the by-products : seeing the gas companies by the new arrangements would subject three times the quantity of coal to the heat of their retorts during the period when the tar and ammoniacal liquors pass off most rapidly, I do not think I am wrong in estimating the yield at double its present amount. Taking this upon the tar and ammonia to yield $3 s .9 d$. per ton of coal, we find the total value of these by-products to be, at present, on the supposed consumption by the gas companies of 2,000,000 tons of coal per annum, 375,000l. This being doubled under my scheme, an additional sum of $375,000 \%$. must be placed to its credit.

But the basis upon which we have hitherto been arguing is that the gas companies under the proposed scheme are getting their coal for nothing. We have been supposing that the community become the purchasers of 6,000,000 tons of coal and hand it to the gas companies. At present London only pays for its general consumption on $4,000,000$ tons of coal and $1,000,000$ tons of coke. Let us now suppose that the companies pay the same sum annually that they do at present for their coals; if so, they would pay upon 2,000,000 tons, or an annual amount of $1,600,000 \%$., if their coals cost $16 s$. per ton. From this falls to be deducted the money they at present draw from their sales of coke, which, when taken at $6 s$. yer ton of coal carbonised under the existing system, still leaves a sum of $1,000,000 l$., which they could afford to pay per annum for the use of the $6,000,000$ tons of fuel as proposed in my siheme. We will now take the total payments of the community for their coal to be upon $6,000,000$ tons, for which we will further suppose they pay at the rate of $16 \mathrm{~s}$ per ton first cost. This would amount to $4,800,000 l$. per annum. From this falls to be dedacted the $1,000,000$ l. contributed by the gas com. panies for the use of the fuel, also the $1,750,000 l$. charged on the difference between the I6- and 24-candle gas already referred to, also the sum of $375,000 \%$. of additional income from the by-products. This would leave a net sum paid by the community for its fuel under my scheme of $1,675,000 l$. Under the present system they have to pay, say $16 s$. per ton on $4,000,000$ tons of coal, and say I2s. per ton on $1,000,000$ tons of colke. This makes in all the sum of $3,800,000$ per annum. Here then we have a balance in favour of my scheme of $2,125,000 /$. annually. This may be taken as the yearly value of London smoke, which I propose to convert into useful products by the plant at present in use.

I have only in conclusion to say one or two words about the efficiency of the scheme as regards the fuel. It lights easily, it gives off no smoke, it makes a cheerful fire, it gives out more heat than either coal or coke, it will be cheaper per heat-unit than the coal at present in use, London would become a smokeless city, and all that would fall to be deducted from the sum of $2,125,000 l$. per annum would be confined to a few items, such as the cost 